\title{
30 Day Prior Medications
}

National Cancer Institute

\section{Source}

National Cancer Institute. 30 Day Prior Medications. NCI Thesaurus. Code C162526.

A header in a CPTAC document regarding medication use 30 days prior. 